\title{
Distribution of ABO Blood Groups and RH (D) factor in Haryana.
}

\author{
Puri P.L. ${ }^{1}$, Kochhar A.K. ${ }^{2}$ \\ ${ }^{1}$ Dr. Prem Lata Puri, Associate Professor, Physiology Department, Maharaja Agrasen Medical College, Agroha, Hisar, \\ Haryana, ${ }^{2}$ Dr. Ajay Kumar Kochhar, Associate Professor, Pathology Department, Maharaja Agrasen Medical College, \\ Agroha, Hisar, Haryan.
}

Address for correspondence: Dr Ajay Kumar Kochhar, E-mail : ajaykochhar10@yahoo.com

\begin{abstract}
Introduction : blood group is a system of antigens present on the surface of red blood cells. The majority are inherited by Mendelian Fashion. The ABO \& Rhesus (Rh) blood group system are the most prevalent \& important for transfusion of blood \& its components, organ transplant, genetic studies \& in legal medicine study. Aim and objective of the study is to determine age and sex wise frequency and distribution of $\mathrm{ABO}$ and $\mathrm{Rh}$ blood group patterns among blood donors in Southern Haryana and compare the data with similar studies. A retrospective study was conducted at Blood bank of Maharaja Agrasen Medical College over a period of six months from $1^{\text {st }}$ January to $30^{\text {th }}$ June 2015 . Blood group of the blood donors were determined by commercially available standard monoclonal antisera by test tube agglutination technique. Results: During the study period 3202 donors of different blood groups were screened by antigen- antibody agglutination method using commercially available antiseras. The study revealed that the commonest ABO blood group was B $(37.82 \%)$, followed by O (30.82\%), A $(22.21 \%)$ and $\mathrm{AB}(9.15 \%)$ respectively. Rh Positive were $91.07 \%$ and $\mathrm{Rh}$ negative were $8.93 \%$. Conclusion: The present study has a significant implication regarding the management of blood bank and transfusion services in this area. It also provides a database for the blood banks and also useful to health planner while making efforts to face future health challenges in the region.
\end{abstract}

Keywords: ABO blood group, Rh factor, Blood donors.

\section{Introduction}

The discovery of the ABO blood group system by Landsteiner in 1900 marked the beginning of modern blood banking and transfusion medicine [1]. He described the blood groups as A, B, and O. Several years later Landsteiner's associates, Von Decastello and Struli, added group AB to the original observations [2]. In his investigations, Landsteiner noted the presence of agglutinating antibodies in the serum of individuals who lacked the corresponding ABO antigen. He observed that group A red cells agglutinated with the serum from group B individuals.

This observation has been termed Landsteiner's rule. The genes of $\mathrm{ABO} \& \mathrm{Rh}$ (D) are located on chromosome $9 \& 1$ respectively. Blood groups are genetically determined. The vast majority are inherited in a simple Mendelian fashion and are stable

Manuscript received $26^{\text {th }}$ April 2016

Reviewed: $13^{\text {th }}$ May 2016

Author Corrected: $27^{\text {th }}$ May 2016

Accepted for Publication $14^{\text {th }}$ June 2016 characteristics which are useful in paternity testing [3]. Blood groups are known to have some association with diseases like duodenal ulcer, diabetes mellitus, urinary tract infection, $\mathrm{Rh}$ incompatibility and $\mathrm{ABO}$ nincompatibility of newborn [4].

There are differences in the distributions of $\mathrm{ABO}, \& \mathrm{Rh}$ (D) blood groups amongst different populations [5,6].

The study of blood grouping is important as it plays an important role in various genetic studies, researching population migration patterns as well as resolving certain medico legal issues, particularly of disputed paternity cases and in blood transfusion practice as it will help a lot in reducing the morbidity and mortality rate [7].

Knowledge of distribution of $\mathrm{ABO} \& \mathrm{Rh}$ blood group is also essential for effective management of blood bank inventory [8]. 


\section{Material and Methods}

A retrospective study of six months was carried out at Blood Bank, Maharaja Agrasen Medical College, Agroha Distt. Hisar. Blood group determination of donors was done from $1^{\text {st }}$ January 2015 to $30^{\text {th }}$ June 2015 at Blood Bank, MAMC Agroha. Total 3202 donors were considered medically fit $\&$ donated blood during the study period. All belonged to age group between 18-55 years.

After blood donation, blood grouping $\mathrm{ABO} \& \mathrm{Rh}$ was done by antigen antibody agglutination test by commercially available standard antiseras i.e Anti-A, Anti-B, Anti-AB and Anti-D were used in our Blood Bank. Blood Group was done by test tube agglutination method. Both forward (cell grouping) \& reverse grouping (serum grouping) method were done. Final blood group was confirmed only if both forward \& reverse groups are identical.

All weak D groups were considered as Rh positive. The donor blood group data were recorded on specially prepared proforma, tabulated, analyzed and compared with the similar studies by other authors.

\section{Results}

Out of 3202 blood donors, majority 3038 (94.88\%) were male and 164 (5.12\%) were female (Table 1). This finding was consistent with the other studies. $80 \%$ of donors were between 18 to 40 yrs. Amongst total 3202 donors most of the donors i.e. 1211 were with blood group B (37.82\%) followed by O (30.82\%), A (22.21\%) and AB (9.15\%).

Table 2 shows distribution of blood donors according to rhesus phenotype. Maximum blood donors i.e. 2916 (91.07\%) were $\mathrm{Rh}+\mathrm{ve}$ while only 286 (8.93. \%) were $\mathrm{Rh}-\mathrm{ve}$. Amongst the ABO blood groups $\mathrm{Rh}+\mathrm{ve}$ donors ranged from 90.30 to $91.33 \%$. Table 3 shows comparison of results of various studies conducted in other parts of India where most of the studies were in consistency with the present study.

Table-1: Sex wise distribution of blood donors.

\begin{tabular}{|c|c|c|c|c|}
\hline Sr. No & Blood groups & No. of Male Donors ( \% ) & $\begin{array}{c}\text { No. Of Female } \\
\text { Donors ( \% ) }\end{array}$ & Total \\
\hline 1 & A & $672(22.12)$ & $39(23.78)$ & $711(22.20)$ \\
\hline 2 & B & $1156(38.05)$ & $55(33.54)$ & $1211(37.82)$ \\
\hline 3 & O & $934(30.74)$ & $53(32.32)$ & $987(30.82)$ \\
\hline 4 & AB & $276(9.09)$ & $17(10.36)$ & $293(9.16)$ \\
\hline \multicolumn{2}{|c|}{ Total } & $\mathbf{3 0 3 8}(\mathbf{1 0 0})$ & $\mathbf{1 6 4}(\mathbf{1 0 0})$ & $\mathbf{3 2 0 2}(\mathbf{1 0 0})$ \\
\hline
\end{tabular}

Table- 2: Distribution of blood donors according to Rhesus Phenotype

\begin{tabular}{|c|c|c|c|c|}
\hline \multirow{2}{*}{ Sr. No } & \multirow{2}{*}{ Blood Groups } & \multicolumn{2}{|c|}{ No. of donors according to Rhesus } & \multirow{2}{*}{ Total } \\
\cline { 2 - 5 } & & \multicolumn{2}{|c|}{ Phenotypes (\%) } & Rh -ve \\
\hline 1. & A & $642(90.30)$ & $69(9.70)$ & $1211(100)$ \\
\hline 2. & B & $1106(91.33)$ & $105(8.67)$ & $987(100)$ \\
\hline 3. & O & $901(91.29)$ & $86(8.71)$ & $293(100)$ \\
\hline 4. & AB & $267(91.13)$ & $26(8.87)$ & $\mathbf{3 2 0 2}(\mathbf{1 0 0})$ \\
\hline
\end{tabular}


Table-3: Comparative study on frequency of $\mathrm{ABO}$ and $\mathrm{Rh}$ phenotypes at different geographical areas (in percentage)

\begin{tabular}{|c|c|c|c|c|c|c|}
\hline Place of Study & $\mathbf{A}$ & $\mathbf{B}$ & $\mathbf{A B}$ & $\mathbf{O}$ & Rh +ve & Rh -ve \\
\hline \multicolumn{7}{|l|}{ Northern part of India } \\
\hline Present study & 22.20 & 37.82 & 9.16 & 30.80 & 91.07 & 8.93 \\
\hline Lucknow [5] & 21.73 & 39.84 & 9.33 & 29.10 & 95.71 & 4.29 \\
\hline Western Rajasthan [7] & 22.2 & 36.4 & 9.4 & 31.7 & 91.75 & 8.25 \\
\hline Punjab [6] & 21.91 & 37.56 & 9.3 & 31.21 & 97.3 & 2.7 \\
\hline \multicolumn{7}{|l|}{ Western Part India } \\
\hline Eastern Ahmedabad [9] & 23.30 & 35.50 & 8.80 & 32.50 & 94.20 & 5.80 \\
\hline Western Ahmedabad [10] & 21.94 & 39.40 & 7.86 & 30.79 & 95.05 & 4.95 \\
\hline Surat [11] & 24.10 & 34.89 & 8.69 & 32.32 & 94.18 & 5.82 \\
\hline \multicolumn{7}{|l|}{ Central Part of India } \\
\hline Indore [12] & 24.15 & 35.25 & 9.10 & 31.50 & 95.43 & 4.57 \\
\hline \multicolumn{7}{|l|}{ Eastern part of india } \\
\hline Durgapur(steel city)[13] & 23.90 & 33.60 & 7.70 & 34.80 & 94.70 & 5.30 \\
\hline \multicolumn{7}{|l|}{ Southern Part of India } \\
\hline Bangalore[14] & 23.85 & 29.95 & 6.37 & 39.82 & 94.2 & 5.8 \\
\hline Vellore[15] & 21.86 & 32.69 & 6.70 & 38.75 & 94.5 & 5.5 \\
\hline Devanagree[16] & 26.15 & 29.85 & 7.24 & 31.76 & 94.8 & 5.2 \\
\hline Shimoga - malnad [17] & 24.27 & 29.43 & 7.13 & 39.17 & 94.93 & 5.07 \\
\hline \multicolumn{7}{|l|}{ Outside india } \\
\hline Pakistan [18] & 22.40 & 32.40 & 30.50 & 8.40 & 93.00 & 7.00 \\
\hline Nepal [19] & 34.00 & 29.00 & 4.00 & 32.50 & 96.70 & 3.30 \\
\hline Britain [20] & 42.00 & 8.00 & 3.00 & 47.00 & 83.00 & 17.00 \\
\hline USA [21] & 41.00 & 9.00 & 4.00 & 46.00 & 85.00 & 15.00 \\
\hline
\end{tabular}

\section{Discussion}

Out of 3202 blood donors, majority 3038 (94.88\%) were male and $164(5.12 \%)$ were female (Table 1$)$. This finding was consistent with the other studies. Eighty percent of donors were between 18 to $40 \mathrm{yrs}$. Amongst total 3202 donors, most of the donors i.e. 1211 were with blood group B (37.82\%) followed by O (30.82\%), A $(22.21 \%)$ and $\mathrm{AB}(9.15 \%)$. Table 2 shows distribution of blood donors according to rhesus phenotype. Maximum blood donors i.e. 2916 (91.07\%) were $\mathrm{Rh}+\mathrm{ve}$ while only 286 (8.93. \%) were $\mathrm{Rh}-\mathrm{ve}$. Amongst the ABO blood groups $\mathrm{Rh}+\mathrm{ve}$ donors ranged from 90.30 to $91.33 \%$. Table 3 shows comparison of results of various studies conducted in other parts of India where most of the studies were in consistency with the present study.

The studies done in Northern parts of India by authors like Tulika Chandra et al [5] at Lucknow, and by Sidhu et al [6] studies at Punjab, Behra Rajshree etal [7] at Jodhpur showed blood group B was the commonest, followed by $\mathrm{O}, \mathrm{A}$ and $\mathrm{AB}$. The same incidence was found in our study i.e. Blood group B was more frequent than $\mathrm{O}$ and followed by $\mathrm{A}$ and $\mathrm{AB}$ blood groups. In Western parts of India like in Eastern Ahmedabad by Wadhwa MK et al [9], Western part of Ahmedabad by Patel, Piyush et al [10]and studies done at Surat by Nidhi et al [11], showed blood group B is the commonest followed by $\mathrm{O}, \mathrm{A}$ and $\mathrm{AB}$ which is same as in our study. Study done at Central India like Indore by Narendra Kumar et al [12] revealed B group to be the most common followed by $\mathrm{O}, \mathrm{A}$ and $\mathrm{AB}$ which is in consonance with present study. Study done in Eastern part of India, Durgapur by Nag I et al [13] showed O group to be the commonest group which is different from our study. In Southern part of India studies done by Periyavan A et al [14] at Bangalore, Das PK Nair et al [15] at Vellore, and at Davanagere by Mallikarjuna $S$ et al [16] and at Shimoga- Malnad study done by Girish et al [17], found that the commonest blood group was $O$ followed by $\mathrm{B}, \mathrm{A}$ and $\mathrm{AB}$ whereas our study showed commonest blood group $\mathrm{B}$ followed by $\mathrm{O}, \mathrm{A} \& \mathrm{AB}$. Geographical distribution of Blood Groups in India 
shows that in Northern \& Western part of India, B is the commonest blood group where as in Eastern Southern and Central part, $\mathrm{O}$ is the most frequently occurring blood group. The incidence of $\mathrm{Rh}+\mathrm{ve}$ blood group in most part of India varies from 91 to $97 \%$ and incidence of $\mathrm{Rh}$-ve varied from 2 to $8 \%$, whereas in our study $91.07 \%$ were $\mathrm{Rh}+\mathrm{ve}$ and $8.93 \%$.were $\mathrm{Rh}$-ve (Table-2) which depicts Rh-ve to be on the higher side in southern haryana as compared to other places in India.

Outside India, in Pakistan, the study was done by Rahman et al [18] the commonest blood group is B which is same as in our study. In Nepal [19] which is connected to western India, as well as, Britain and USA, 'O' and 'A' are the common blood groups that are followed by $\mathrm{B}$ and $\mathrm{AB}$. While looking at $\mathrm{Rh}$ grouping, 89-95\% donors all over the world are detected as Rh+ve except at Britain [20] and U.S.A. [21] where the frequency of $\mathrm{Rh}$ positivity is $83-85 \%$. Here it is a well known fact that many of the people residing at USA have migrated from Britain.

There is known genetic association of specific blood groups to the certain diseases in certain population. Studies concerned about possible association between ABO blood group and cardiovascular diseases have confirmed that persons of group A are affected more frequently with coronary heart disease, ischemic heartdisease, venous thrombosis and atherosclerosis, while its low in people with blood group ' $O$ ' which stated to have protective effect against these diseases [22,23]. 'O'group individuals are known to have a $14 \%$ reduced risk of squamous cell carcinoma and $4 \%$ reduced riskof basal cell carcinoma when compared to non-O group [24]. It is also associated with a reduced risk of pancreatic cancer $[25,26]$. The ' $\mathrm{B}$ ' antigen links withincreased risk of ovarian cancer [27]. Gastric cancer has reported to be more common in blood group 'A' and least in group 'O' [28]. Apart from transfusion service, knowledge of the blood group system helps to take preventive measures against these diseases.

\section{Conclusion}

It is concluded that the total 3202 blood donors were studied for group wise distribution. We observed that the most common blood group was B (37.82\%) followed by $\mathrm{O}(30.82 \%), \mathrm{A}(22.20 \%)$ and $\mathrm{AB}(9.16 \%)$ amongst Rhesus (Rh) $91.07 \%$ were $\mathrm{Rh}+\mathrm{ve}$ and $8.93 \%$ Rh-ve. Blood donation by the females was very low and it needs to be increased by improving health status and awareness about blood donation. The present study has a significant implication regarding the management of blood bank and transfusion services in the area and helps to prepare a database for the blood banks. Simple database of blood groups provides data about the availability of human blood in case of regional calamities, but also suggests the further scope of improvement in blood transfusion services and also useful to health planner while making efforts to face future health challenges in the region.

Funding: Nil, Conflict of interest: None initiated. Permission from IRB: Yes

\section{References}

1. Land steirier K. Zur Kenntnis der antifermentativen, lytischenand agglutinierenden wirkungen des Blutserums under lymphe. Zentralblatt Bakteriologic. 1900; 27:357-62.

2. Von decastella A, Sturli A. Ureber die iso agglutinine in serumgesunder and Kranaker Menschen" Mfiner Med WSchr. 1902;49:1090-5.

3. Hoffbrand A V and Pettit J E. Blood Transfusion in Essential Haematology, Oxford UK, Black well scientific Publication. 5th Edition 2006; 307-9.

4. Skaik Y, El-Zyan N. Spectrum of ABO and Rh (D) blood groups amongst the Palestinian students at AlAzhar University-Gaza. Pak J Med Sci. 2006;22: 333-5.

5. Chandra T, Gupta A. Frequency of $\mathrm{ABO}$ and rhesus blood groups in blood donors. Asian J Transfus Sci. 2012 Jan;6(1):52-3. doi: 10.4103/0973-6247.95057.

6. Sidhu S. Distribution of the ABO Blood Groups and Rh(D) factor among the Scheduled Caste Population of Punjab. Anthropologist. 2003;5(3):203-204.

7. Behra Rajshree, Joshi Yogi Raj. Distribution of the ABO Blood Groups and $\mathrm{Rh}(\mathrm{D})$ factor in western Rajasthan. National Journal of Medical Research. 2013;3(1): 73-75

8. Enosolease ME, Bazuaye GN. Distribution of ABO and $\mathrm{Rh}-\mathrm{D}$ blood groups in the Benin area of NigerDelta: Implication for regional blood transfusion. Asian J Transfus Sci. 2008 Jan;2(1):3-5. doi: 10.4103/09736247.39502 .

9. Wadhwa MK, Patel SM, Kothari DC, Pandey M, Patel DD. Distribution of ABO and Rhesus D groups in Gujrat, India-a hospital based study. Indian J Ped Oncol. 1998;19(4):137-141. 
10. Patel Piyush A, Patel Sangeeta P, Shah Jigesh V, Oza Haren V. Frequency and distribution of Blood Groups in Blood Donors in Western Ahmedabad - A Hospital based study. National J. Med. Res. 2012; 2(2):207-210.

11. Mehta Nidhi, Swadas Bhawna. Prevalence of ABO Blood groups at Mahavir Heart Institute Surat. Asian J. Trans.Sci. 2012;6(1):74.

12. Gupta Narendra Kumar, Dadwal S. Distribution of ABO and Rhesus-D Blood groups. Asian J. Trans. Sci. 2012; 6(1):73.

13. Nag I, Das SS. ABO and Rhesus blood groups in potential blood donors at Durgapur Steel city of the district of Burdwan, West Bengal. Asian J Transfus Sci. 2012 Jan; 6(1):54-5. doi: 10.4103/0973-6247.95059.

14. Periyavan S, Sangeetha SK, Marimuthu P, Manjunath BK, Seema DM. Distribution of ABO and Rhesus-D blood groups in and around Bangalore. Asian J Transfus Sci. 2010 Jan;4(1):41. doi: 10.4103/09736247.59391.

15. Das PK, Nair SC, Harris VK, Rose D, Mammen JJ, Bose YN, Sudarsanam A. Distribution of ABO and RhD blood groups among blood donors in a tertiary care centre in South India. Trop Doct. 2001 Jan;31(1):47-8.

16. Mallikarjuna S. Prevalence of $\mathrm{ABO}$ and Rhesus blood group among blood donors. Indian J. Pub. Health, Research and Development. 2012:3(2):106-109.

17. Girish C J, Chandrashekhar TN, Ramesh Babu K, Kantikar SM. ABO and Rhesus blood group distribution among Malnad region blood donors Research and Reviews in Biomedicine and Biotechnology (RRBB). 2011;2(3):25-30.

18. Rahman $\mathrm{M}$ and Lodhi $\mathrm{Y}$. Frequency of $\mathrm{ABO}$ and Rhesus blood groups in blood donors in Punjab. Pak J Med Sci 2004; 20:315-8.
19. Pramanik T, Pramanik S. Distribution of ABO and Rh blood groups in Nepalese medical students: a report. East Mediterr Health J. 2000 Jan;6(1):156-8.

20. Frances TF: Blood groups (ABO groups). In: Common Laboratory and Diagnostic Tests. 3rd Edition, Philadelphia: Lippincott, 2002; p.19-5.

21. Firkin F., Chesterman C, Penington D, \& Rush B.: De Gruchy's Clinical haematology in medical Practice. Blackwell Science Publisher, $5^{\text {th }}$ Edition, 2008; Pp-475.

22. Khan MI, Micheal S, Akhtar F, Naveed A, Ahmed A, Qamar R. Association of ABO blood groups with glaucoma in the Pakistani population. Can J Ophthalmol.2009Oct;44(5):582-6. doi:10.3129/i09-104.

23. Alam M. ABO and Rhesus blood groups in potential blood donors at Skardu (Northern Areas). Pakistan Journal of Pathology. 2005; 16: 94-97.

24. Xie J, Qureshi A A, Li Y, Han J, (2010). ABO Blood Group and Incidence of Skin Cancer. PLoS ONE 2010;302(5):319-339.

25. Wolpin B M, Kraft P, Gross M, Helzlsouer K, et al. Pancreatic cancer risk and $\mathrm{ABO}$ blood group alleles: results from the pancreatic cancer cohort consortium. Cancer Res. 2010; 70 (3):1015-23.

26. Amundadottir L, Kraft P, Stolzenberg-Solomon RZ, etal. Genome-wide association study identifies variants in the $\mathrm{ABO}$ locus associated with susceptibility to pancreatic cancer. Nat Genet. 2009 Sep;41(9):986-90. doi: 10.1038/ng.429. Epub 2009 Aug 2.

27. Gates MA, Wolpin BM, Cramer DW, Hankinson SE, Tworoger SS. ABO blood group and incidence of epithelial ovarian cancer. Int J Cancer. 2011 Jan 15;128 (2):482-6.doi:10.1002/ijc.25339. Epub 2010 Mar 22.

28. AIRD I, BENTALL HH, ROBERTS JA. A relationship between cancer of stomach and the $\mathrm{ABO}$ blood groups. Br Med J. 1953 Apr 11;1(4814):799-801.

\section{How to cite this article?}

Puri P.L, Kochhar A.K. Distribution of ABO Blood Groups and RH (D) factor in Haryana. Int J Med Res Rev 2016;4 (6):982-986.doi: 10.17511/ijmrr.2016.i06.20. 